\title{
Medical marijuana: a public health perspective
}

\author{
Ushang Desai ${ }^{\mathrm{a} *}$, Paras $^{\text {Patel }^{\mathrm{b}}}$
}

\begin{abstract}
${ }^{a}$ Department of Environmental \& Occupational Health, College of Public Health, University of South Florida, Tampa, FL 33612, USA, ${ }^{\mathrm{b}}$ College of Pharmacy, Nova Southeastern University, Fort Lauderdale-Davie, FL 33314, USA
\end{abstract}

Received: 17 January 2013

Accepted: 27 January 2013

*Correspondence to:

Dr. Ushang Desai,

Email: drushang@gmail.com

(C) 2013 Desai U et al. This is an open-access article distributed under the terms of the Creative Commons Attribution License, which permits unrestricted use, distribution, and reproduction in any medium, provided the original work is properly cited.

\begin{abstract}
Over the few years medical marijuana is growing in the United States. Because of the medical marijuana legislators able to legalized recreational marijuana in the two states in the US. Marijuana has several potential benefits that help in certain disease. The delivery of marijuana is also important because smoking marijuana has severe side effects. Physicians also play important role in medical marijuana, physicians also divided on the use of medical marijuana. Their attitude towards medical marijuana important for the treatment of disease is important for the community. Marijuana is the most commonly used illegal drug in the US and all over world, several risks associated with it. Major concern is medical marijuana increased the use of marijuana and will create the public health problem in the society. There are several medical benefits from the marijuana but require more research to establish the marijuana as a medicine. Control of medical marijuana is also major issue for the law enforcement agencies and challenge for policymakers also in the United States.
\end{abstract}

Keywords: Medical Marijuana, Physicians, Public Health, Medical Benefits, Health Risks

\section{INTRODUCTION}

On November $6^{\text {th }} 2012$, Election Day in the United States of America, in 50 states and District of Columbia American people were deciding for their president but three states Colorado, Washington and Oregon voted for legalizing recreational use of marijuana. Colorado and Washington legalized marijuana for recreational use but Oregon failed to pass the law for legalization of marijuana for recreational use. Why we are discussing these issues because medical marijuana law paved for the legalization of the recreation use of marijuana in the two states in the US. It means you can carry small amount of marijuana legally in the Colorado and Washington states in the US. There are several legal issues related to possession of marijuana but it will take time make more defined laws in these states. According to Drug Enforcement Agency, Marijuana is properly categorized under Schedule I of the Controlled Substances Act (CSA), 21 USC $\S 801$ et.esq. But Marijuana legalized in 18 states and District Columbia as a medical use. Medical Marijuana use has increased in these states and cities where it's medically legal and now it's legal for recreational purposes in two states. There are several issues related to medical marijuana which concern public health such as its medical use, harmful effects, laws and physicians role. During past fifteen year's new type of drug stores opened in the United States that distribute illicit drug substance-medical marijuana dispensaries. Marijuana is the most commonly used illicit substance in the United States, chronic regular use of marijuana related with DSM-IV categorized marijuana use disorders. ${ }^{1-4}$ These disorders are connected with several other issues such as marijuana withdrawal, unemployment, personality dysfunction, crime, respiratory problems and other psychiatric disorders. ${ }^{5-8}$

\section{MARIJUANA AND MEDICAL USES}

Scientific communities as well as people have divided opinion about the medical use of marijuana. As people voted in 1996 for legalization of medical marijuana first time in the United States, in January 1997, the White House Office of National Drug Control Policy (ONDCP) asked Institute of Medicine (IOM) to look for scientific evidence for medicinal benefits and risks of marijuana. IOM started review in August 1997 and submitted their report on "Marijuana and Medicine". This study gave 
some conclusion and recommended certain suggestion on marijuana and use as medicine. IOM report suggested that scientific data suggested the potential therapeutic benefits of cannabinoid drugs, primarily THC (Tetrahydrocannabinol-a principal component of cannabis plant) for pain relief, control of nausea and vomiting, and appetite stimulation are medicinal benefits of marijuana. This report suggested that smoked marijuana is crude delivery system of THC and also delivers harmful substances along with that. They came to conclusion that the psychological effects of cannabinoid, such as anxiety reduction, sedation, and euphoria can affect potential therapeutic benefits of marijuana. These effects are harmful to someone or beneficial for others, also these effects can difficult to understand the other aspects of the drug's effect.

\section{Analgesia}

IOM study concluded that required further research into the circuitry underlying cannabinoid analgesic should be evaluated. Several neural pathways that underlie the control of pain suggest that there are synergistic effects on analgesia by cannabinoid. One of them is involvement of a $\alpha_{2}$ adrenoreceptor in cannabinoid analgesia. IOM recommended that following patients required clinical studies of cannabinoid in the treatment of pain ${ }^{9}$ :

1. Patients on chemotherapy, especially treated for the mucositis, nausea, and anorexia

2. Patient with postoperative pain

3. Patients with chronic pain and insomnia

4. Patients with spinal cord injury, peripheral neuropathic pain or central post-stroke pain

5. AIDS patients with cachexia, neuropathy or any pain problems

\section{Chemotherapy Induced Nausea and Vomiting}

IOM study found that most patients with chemotherapy are unlikely to use marijuana or THC as an anti-emetic. Until the development of new rapid-action anti-emetic drug delivery system some people preferred to use marijuana or THC as anti-emetic in whom standard antiemetic therapy is not effective. The benefits outweighs the side-effects of smoking marijuana consider in these patients on a case-by-case basis and managed under medical observation.

\section{Wasting Syndrome in AIDS and Appetite Stimulation}

Efficacy of marijuana and THC suggested they are potential for the treatment of wasting syndrome in AIDS patients. ${ }^{9}$ Clinical manifestations such as nausea, appetite loss, pain and anxiety of wasting syndrome of AIDS can be treated by marijuana. There are some medications are more effective than marijuana in treatment of wasting syndrome but not equally effective in all patients. Rapid delivery system should be develop for marijuana for the treatment of wasting syndrome, smoking marijuana is not recommended for wasting syndrome. ${ }^{9}$ For patients at terminal stage of disease suffering from debillating pain or nausea and for whom all prescribed medications have failed to provide any help, the medical benefits of smoking marijuana may be outweigh the harmful effects of it.

\section{Neurological Disorders}

Muscle Spasticity: There are several anecdotal reports suggested that marijuana can relieve the spasticity related with multiple sclerosis or spinal cord injury and also animal studies have shown that cannabinoids affect motor areas in the brain areas that may affect the spasticity. ${ }^{10-13}$ As discussed earlier prevalence of the anecdotal reports of the relief of muscle spasticity by marijuana, required carefully designed clinical trials testing the effects of cannabinoids on muscle spasticity should be considered. ${ }^{14,15}$

Movement Disorders: Compared to significant anecdotal reports concerning the beneficial effects of marijuana on muscle spasticity, there is relatively fewer evidence that marijuana is useful for the treatment of movement disorders. ${ }^{9}$ There are no published survey found that suggested that patients with movement disorders got relief from marijuana.

Epilepsy: Though cannabinoids have anti-epileptic properties, several studies conducted to assess these properties, these studies are too small to established efficacy of cannabinoids in treatment of epilepsy. Generally to prove the anti-epileptic effects, clinical studies require large number of patients followed for months because the frequency of seizures is highly variable and response to therapy different for seizures type. ${ }^{16-17}$ Based on the current knowledge of the clinical studies of cannabinoids in the treatment of epilepsy, further studies in the treatment of epilepsy are not recommended. ${ }^{9}$

Alzheimer's disease: There is one study conducted on 11 patients' with Alzheimer's disease were treated with dronabinol for 12 weeks on alternative schedule (6 weeks on dronabinol and 6 weeks on placebo), treatment suggested that patients gained substantial weight and declined in disturbed behavior. ${ }^{18-19}$ These results were encouraging for future clinical studies in the treatment of Alzheimer's disease. Short-term memory loss is a common side effect of THC in healthy patients but this is not significant in this study.

\section{Glaucoma}

Several clinical studies on the effects of smoked marijuana on glaucoma did not show any effective results and potential harmful effects of chronic marijuana smoking outweigh its modest effects in the treatment of glaucoma. ${ }^{9}$ Future researches require seeing the longer 
lasting effects on intra ocular pressure and fewer side effects.

In November 2009, State of Colorado passed Amendment 20, which allows an assenting defense for the use and possession of marijuana by people with one of the following eight debilitating medical conditions such as HIV/AIDA, glaucoma, severe nausea, severe pain, cancer, seizures and muscle spasms. ${ }^{42}$

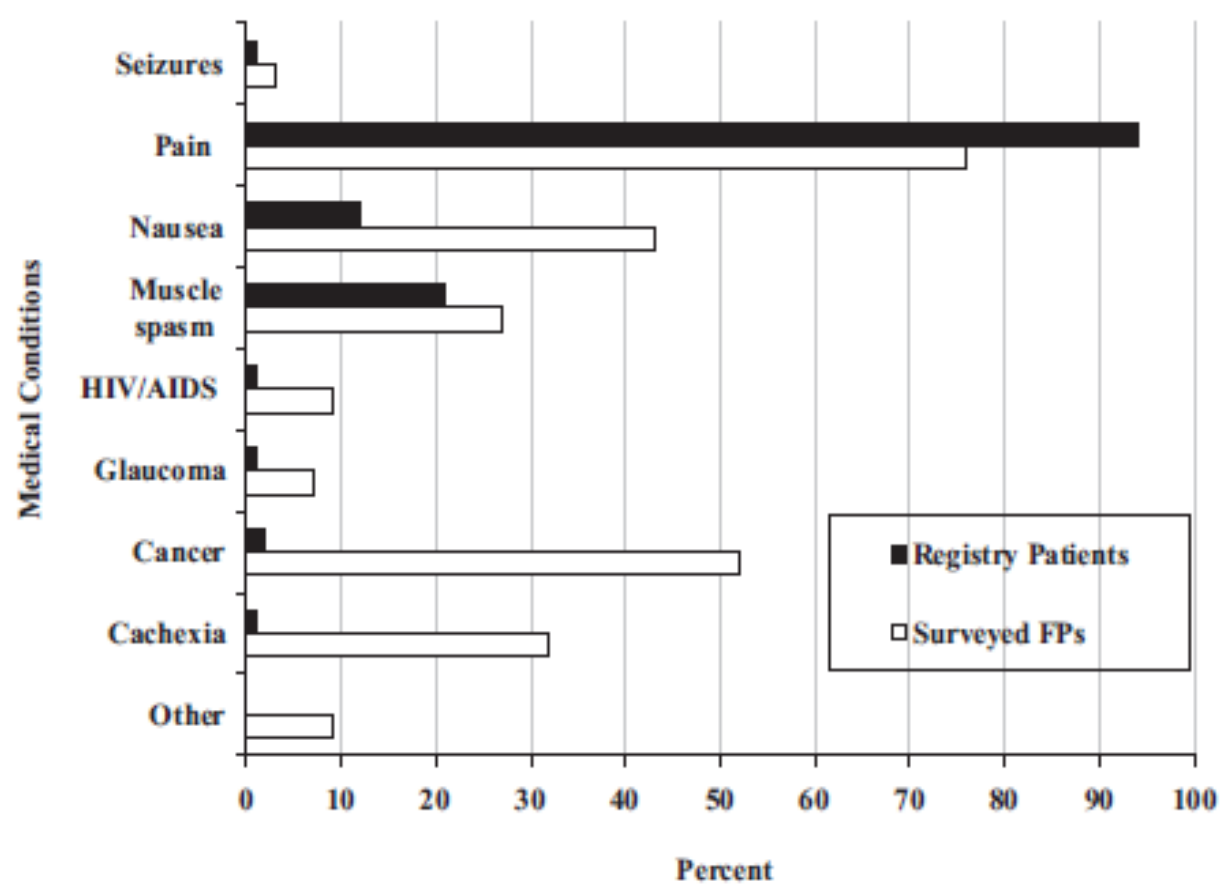

Figure 1: Indications for which family physicians (FPs) are recommending medical marijuana "Registry patients" indicates percentages of patients on the Colorado state medical marijuana registry for each indication shown, according to the Colorado Department of Public Health and the Environment. "Surveyed FPs" indicates the percentage of survey respondents who had recommended medical marijuana for each indication. ${ }^{44}$

According to the Colorado Department of Public Health and the Environment, as of $31^{\text {st }}$ December, 2011, $94 \%$ of registrants were using medical marijuana for chronic pain and $17 \%$ for muscle spasms. ${ }^{42}$

\section{MEDICAL USE AND DRUG ABUSE AND OTHER CONCERNS}

The concern with medical marijuana use is drug abuse among the population in particular teenagers. University of Michigan conducted the monitoring the future survey since 1975, found that the rate of using marijuana in youths is inversely related to "perceived risk" and "perceived social disapproval". ${ }^{20}$

In 2011, daily marijuana use among $12^{\text {th }}$ grade was at highest level in the past 30 years. $^{20}$ There is also valid concern that medical marijuana is stalking horse to legalize marijuana use and we saw that they succeeded to legalize recreational marijuana in two states (Colorado and Washington) in the US. Increasing the use of medical marijuana and legalization of recreational marijuana in the US might be expected to decrease the perceptions of both risk and social disapproval of marijuana use in youths. There are potential side-effects of marijuana using for medical or recreational purposes. ${ }^{21,22}$ Approximately $9 \%$ of marijuana users will become dependent ${ }^{23}$ and number of addicted to marijuana will likely to rise as more easily available. Currently $61 \%$ of Americans ages 12 and older who meet diagnostic criteria for substance abuse or dependence on any other drugs other than alcohol because of their marijuana use. ${ }^{24,25}$ Immediate stop of marijuana use has been associated with physical withdrawal syndrome ${ }^{26-29}$ and with relapse after treatment as high as $71 \% .^{30}$ Severe side-effects are associated with marijuana use are, greater marijuana dependence $^{31}$; more traffic accidents because of drugged driving $^{32}$; short-term memory deficits, decreased concentration and thought processing ${ }^{21}$; and aggravation of existing schizophrenia symptoms and course ${ }^{33-37}$, relapse of schizophrenia symptoms and earlier onset of schizophrenia in vulnerable males. Chronic marijuana smoking associated with acute and chronic bronchitis and found pathological abnormalities in cell lining in the bronchial passageways, some of which may be premalignant. ${ }^{9}$ This respiratory pathology is similar to 
those associated with tobacco smoking, and combination of tobacco and marijuana smoking enhances these sideeffects. There is probability of association between chronic marijuana smoking and COPD. ${ }^{9}$ The most important concern associated with marijuana smoking and HIV/AIDS patients are the possible effects on the immunity of the patients. ${ }^{38}$ There are several reports of opportunistic bacterial and fungal infections among AIDS patients who used marijuana suggested that marijuana smoking either repress the immune system in the patients $^{39}$ or person used marijuana exposed to more pathogens. ${ }^{40}$ Institute of Medicine report suggested that a characteristic marijuana withdrawal syndrome has been acknowledged, but it is mild and short-period. This syndrome consists of restlessness, irritability, mild agitation, insomnia, sleep EEG disturbances, nausea and cramping. Several studies suggested that marijuana smoke is an important risk factor in the development of respiratory disease.

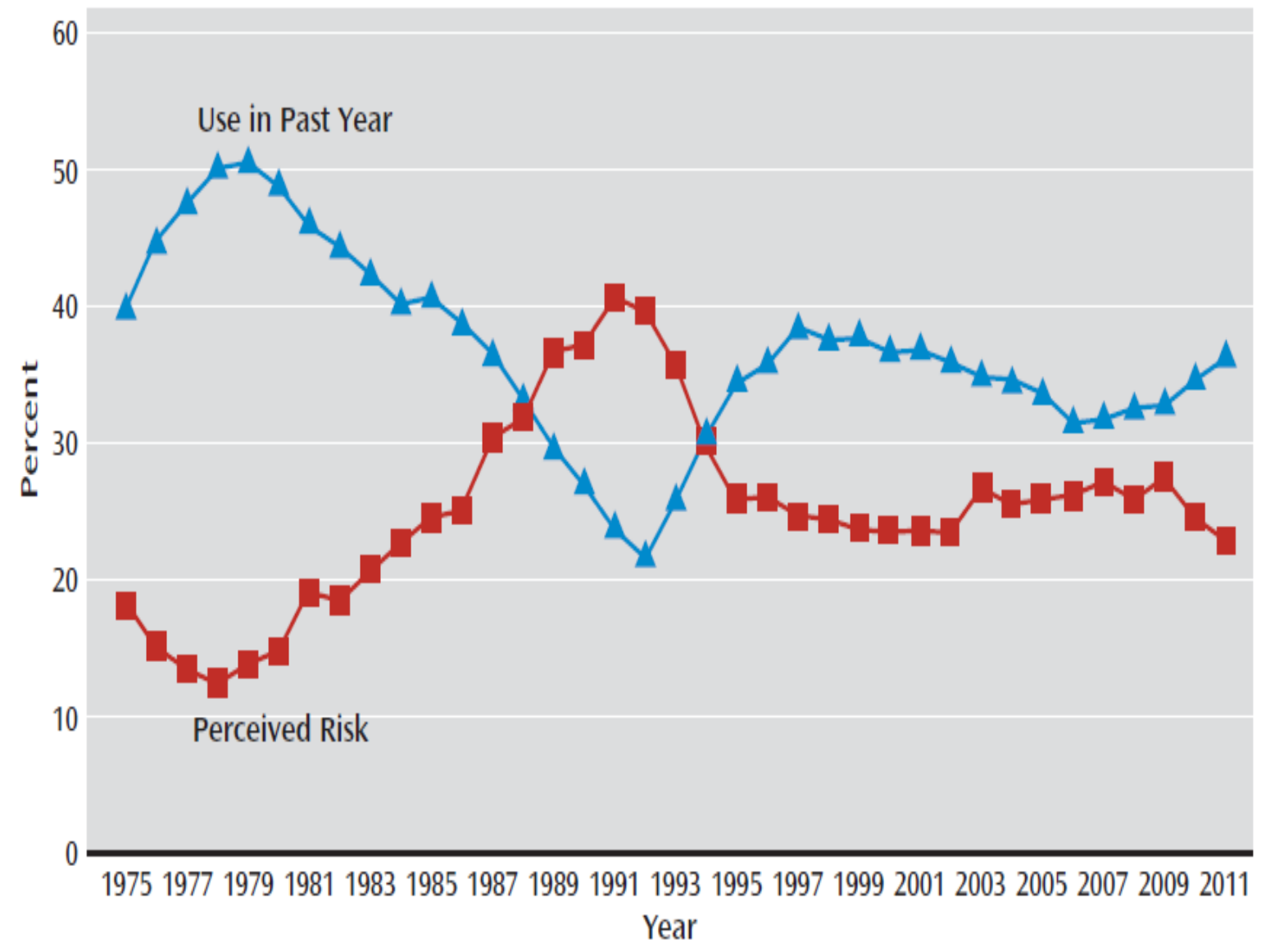

Figure 2: Trends in Annual Marijuana Use and Perceived Risk* Among 12th Graders.

*Risk means percent saying great risk of harm in occasional use. Figure based on data from the monitoring the Future Study, University of Michigan. ${ }^{20}$

\section{ROLE OF PHYSICIANS IN MEDICAL MARIJUANA}

Medical marijuana control is one of the major responsibilities of the physicians also. In the US, marijuana dispensaries are opening like McDonald's or Starbucks. When cities tried to regulate the number of these dispensaries and their location (not within 1000 feet of schools or playgrounds) or attempt to close these dispensaries because of criminal activities associated with it, they face legal actions from these dispensaries. In certain areas, school district felt they are surrounded by these dispensaries. $^{41}$
In state of Colorado to get a medical marijuana registry card, patients must complete an application that requires physician certification that may be completed by any Colorado-licensed physician, confirming that they have one of the eight conditions discussed above and might be benefited from the use of medical marijuana. There is survey conducted in state of Colorado to view family physicians attitude towards medical marijuana, this survey conducted in state of Colorado because it is one of the states that fulfills and publicly releases data about the people who apply to the state's medical marijuana registry. Now this survey also important as Colorado legalizes recreational marijuana, to understand the attitude of family physicians in the medical marijuana. 
According to Colorado medical marijuana registry, most of the patients recommended for medical marijuana by small number of physicians; $49 \%$ of medical marijuana recommendations have been made by only 15 physicians. ${ }^{43}$ The aim of this survey was to look for regulation of medical marijuana at the physicians' level and requirement for medical knowledge for rapidly growing new area of medical practice.

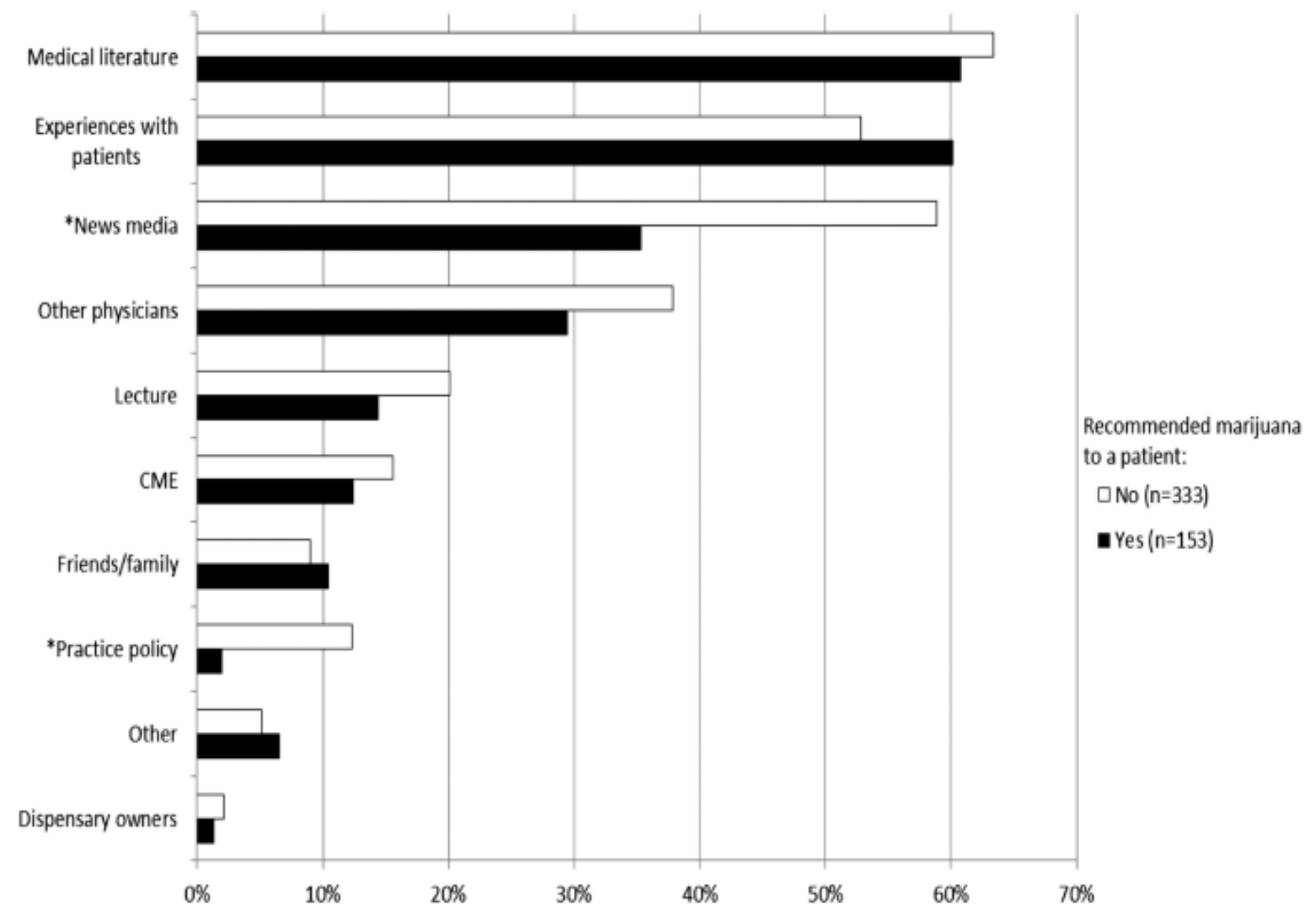

Figure 3: Sources of information about medical marijuana indicated by survey respondents, broken down by whether respondents had recommended medical marijuana for a patient. *Difference in proportions is statistically significant $(\boldsymbol{p}<\mathbf{0 . 0 1})$. CME-continuing medical education ${ }^{44}$

Figure 3 identifies the sources form where family physicians reported in surveys getting most of their information about medical marijuana. Family physicians who did not recommend medical marijuana for a patient responded that new media and practice policy as sources of their information. Of the responding physicians in this survey $46 \%$ said that physicians should not recommend marijuana as a medical therapy at all; 19\% said that physicians should recommend marijuana as a medical therapy. ${ }^{44}$ Most of the physicians on survey agreed that there are significant health risks such as physical $(61 \%)$ and mental (64\%) with marijuana use; only few physicians disagreed that there are not significant risks [physical (18\%) and mental (15\%)] with marijuana use. In survey physicians responded about benefits of marijuana use, $27 \%$ of surveyed agreed that significant physical health benefits, while $41 \%$ disagreed with it. $15 \%$ physicians agreed that there are significant mental health benefits while $54 \%$ disagreed with it. This survey looked for the factors that influence the decisions of the physicians in the recommending of medical marijuana (Figure 4).
Ninety-five percent of respondent physicians agreed that physicians should not be allowed to have financial relationships with marijuana dispensaries, which also forbidden by State of Colorado; $63 \%$ of respondent agreed that medical marijuana should not allow through current dispensary system, only $10 \%$ respondents agreed on current dispensary system. Most of the physicians agreed that further medical training required for medical marijuana; $80 \%$ agreed that training should be incorporated into medical school curricula, and $82 \%$ responded that it should be part of family medicine residency training; 92\% agreed that continuing medical education (CME) should be available to primary care physicians about medical marijuana; $82 \%$ responded that physicians should have formal training before recommending medical marijuana. ${ }^{44}$

One of the most important challenge for the physicians to recommend their patients the use of schedule I illegal drug (according to DEA) of abuse with no FDA approval, dosage control or quality control. ${ }^{45}$ Several professional 
medical societies such as the American Medical Association, the American Society of Addiction Medicine, the American Psychiatric Association, have considered the medical marijuana movement and oppose this movement. The American Society of Addiction Medicine specifically recommended that "its members and other physicians organizations and their members reject responsibility for providing access to cannabis and cannabis-based medications until such time as they receive marketing approval from the FDA." "45 Physicians role is to clearly explain to their patients that medical marijuana is not scientifically approved by FDA and this is not standardized or purified marijuana that has obtained scientific approval and is available in pharmacies through prescriptions. ${ }^{45}$

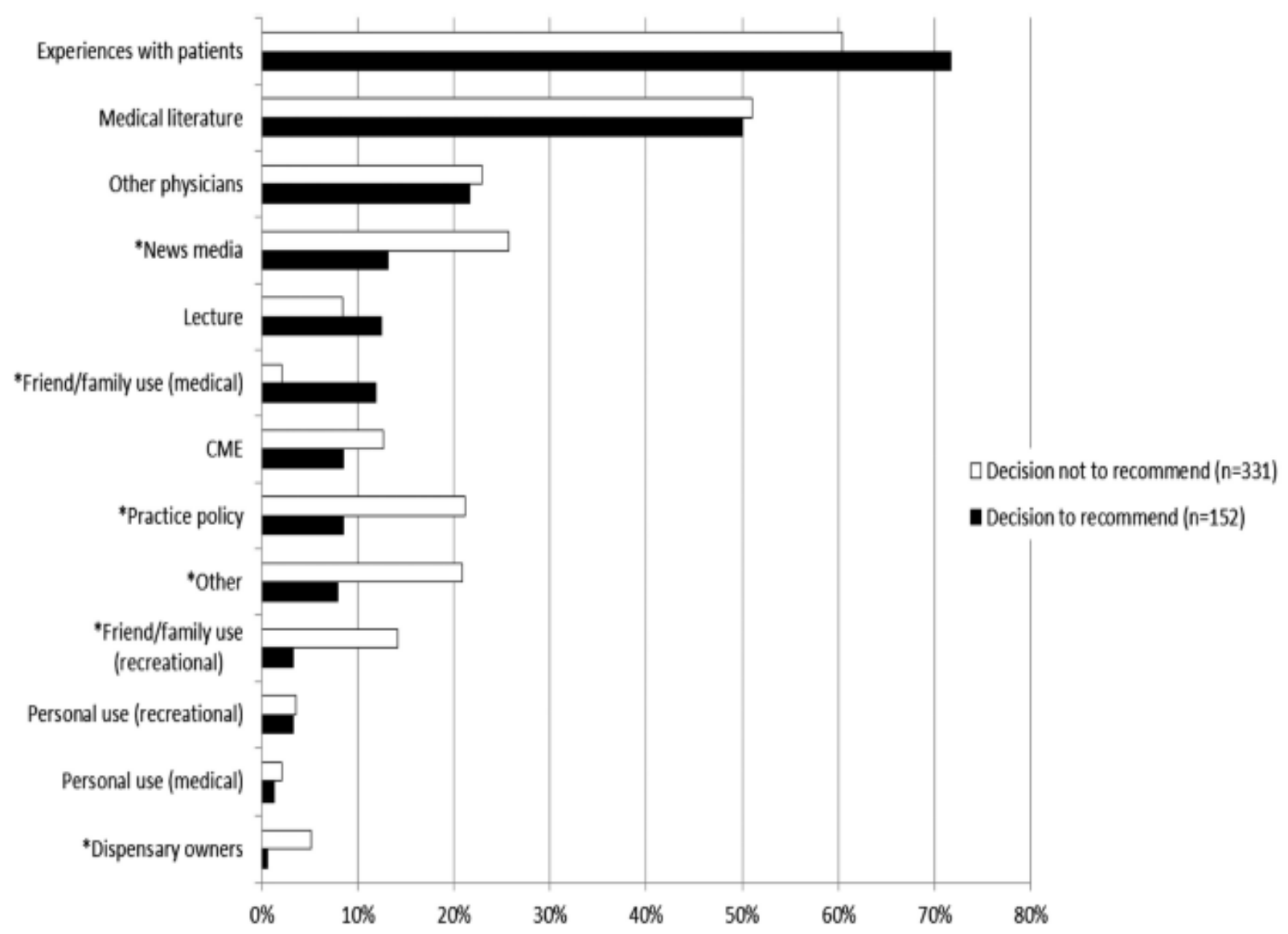

Figure 4: Influences on the decision to recommend or not recommend medical marijuana to a patient, as reported by survey respondents. *Difference in proportions is statistically significant $(p<0.01)$. CME-continuing medical education

\section{CONCLUSION}

Marijuana and/or THC has several medical efficacy in the treatment of several diseases but smoking marijuana is crude delivery system. We should look for the new rapid onset delivery system for cannabinoids that help for the patients for the future use. It also requires vigorous scientific approval from FDA before using it. Marinol (dronabinol) is the only cannabinoid with approval for marketing in the United States. This drug helped to develop for the new cannabinoid drugs as well as regulatory and commercial fate for new cannabinoid drugs.

Funding: No funding sources
Competing interests: None declared

Ethical approval: Not required

\section{REFERENCES}

1. Grant BF, Pickering R. The relationship between cannabis use and DSM-IV cannabis abuse and dependence: results from the national longitudinal alcohol epidemiologic survey. J Subst Abuse 1998;10:255-64.

2. American Psychiatric Association. Diagnostic and Statistical Manual of Mental Disorders. 4th edition. Washington, DC: American Psychiatric Association; 2000 . 
3. Johnston LD, O’Malley PM, Bachman JG, Schulenberg JE. Monitoring the Future National Survey Results on Drug Use, 1975-2009. Volume I: Secondary school students. NIH Publication No 10 7584. National Institute on Drug Abuse; Bethesda, MD: 2010.

4. Compton W, Thomas Y, Stinson FS, Grant B. Prevalence, correlates, disability, and comorbidity of DSM-IV drug abuse and dependence in the United States - results from the National Epidemiologic Survey of Alcohol and Related Conditions. Arch Gen Psychiatry 2007;64:566-76.

5. Pedersen W, Skardhamar T. Cannabis and crime: findings from a longitudinal study. Addiction 2010;105:109-18.

6. Hasin DS, Keyes KM, Alderson D, Wang S, Aharonovich E, Grant BE. Cannabis withdrawal in the United States: results from NESARC. J Clin Psychiatry 2008;69:1354-63.

7. Hall W, Lynskey M. The challenges in developing a rational cannabis policy. Curr Opin Psychiatr 2009;22:258-62.

8. Haney M. The marijuana withdrawal syndrome: diagnosis and treatment. Curr Psychiatry Rep 2005;7:360-6.

9. Marijuana and Medicine: Assessing the Science Base. Joy J, Watson S, Benson J, Institute of Medicine, 1999, National Academic Press, ISBN 0309-51408-8.

10. Glass M, Dragunow M, Faull RLM. Cannabinoid receptors in the human brain: A detailed anatomical and quantitative autoradiographic study in the fetal, neonatal and adult human brain. Neuroscience 1997;77:299-318.

11. Herkenham M, Lynn AB, de Costa BR, Richfield EK. Neuronal localization of cannabinoid receptors in the basal ganglia of the rat. Brain Res 1991;547:267-74.

12. Miller AS, Walker JM. 1996. Electrophysiological effects of a cannabinoid on neural activity in the globus pallidus. Eur J Pharmacol 304:29-35.

13. Sanudo-Pena MC, Walker JM. 1997. Role of the subthalamic nucleus in cannabinoid actions in the substantia nigra of the rat. $J$ Neurophysiol 1997;77:1635-8.

14. Consroe P. Clinical and experimental reports of marijuana and cannabinoids in spastic disorders. In: Nahas GG, Sutin KM, Harvey DJ, Agurell S, Editors, Marijuana and Medicine. Totowa, NJ: Humana Press; 1998.

15. Grinspoon L, Bakalar JB. Marijuana: The Forbidden Medicine. New Haven: Yale University Press; 1993.

16. Ames FR. Anticonvulsant effect of cannabidiol. S Afr Med J 1986;69:14.

17. French J. The art of antiepileptic trial design. Adv Neurol 1998;76:113-23.

18. Volicer L, Smith S, Volicer BJ. Effect of seizures on progression of dementia of the Alzheimer type. Dementia 1995;6:258-63.
19. Volicer L, Stelly M, Morris J, McLaughlin J, Volicer BJ. 1997. Effects of dronabinol on anorexia and disturbed behavior in patients with Alzheimer's disease. Int J Geriatr Psychiatry 1997;12:913-9.

20. Johnston LD, O'Malley PM, Bachman JG, Schulenberg JE: Monitoring the Future National Survey Results Adolescent Drug Use: Overview of Key Findings, 2011. Ann Arbor, Institute for Social Research, The University of Michigan, 2012.

21. Hall W. The adverse health effects of cannabis use: what are they, and what are their implications for policy? Int J Drug Policy 2009;20:458-66.

22. Kalant H. Adverse effects of cannabis on health: an update of the literature since 1996. Prog Neuropsychopharmacol Biol Psychiatry 2004;28:849-63.

23. Anthony L, Warner L, Kessler R. Comparative epidemiology of dependence on tobacco, alcohol, controlled substances, and inhalants: basic findings from the National Comorbidity Study. Clin Exp Psychopharmacol 1994;2:244-68.

24. Substance Abuse and Mental Health Services Administration: Results from the 2010 National Survey on Drug Use and Health: Summary of National Findings: NSDUH Series 11-14. DHHS Publication (SMA) 11-4658. Rockville, Md, Substance Abuse and Mental Health Services Administration, 2011.

25. Grant BF, Stinson FS, Dawson DA, Chou SP, Dufour MC, Compton W, Pickering RP, Kaplan K. Prevalence and co-occurrence of substance use disorders and independent mood and anxiety disorders: results from the National Epidemiologic Survey on Alcohol and Related Conditions. Arch Gen Psychiatry 2004;61:807-16.

26. Haney M, Ward AS, Comer SD, Foltin RW, Fischman MW. Abstinence symptoms following smoked marijuana in humans. Psychopharmacology (Berl) 1999; 141:395-404.

27. Budney AJ, Moore BA. Development and consequences of cannabis dependence. J Clin Pharmacol 2002;42(11. Suppl):28S-33S.

28. Budney AJ, Hughes JR, Moore BA, Vandrey R. Review of the validity and significance of cannabis withdrawal syndrome. Am J Psychiatry 2004;161:1967-77.

29. Haney M. The marijuana withdrawal syndrome: diagnosis and treatment. Curr Psychiatry Rep 2005;7:360-6.

30. Moore BA, Budney AJ. Relapse in outpatient treatment for marijuana dependence. J Subst Abuse Treat 2003;25:85-9.

31. Cerda M, Wall M, Keyes KM, Galea S, Hasin D. Medical marijuana laws in 50 states: investigating the relationship between state legalization of medical marijuana and marijuana use, abuse, and dependence. Drug Alcohol Depend 2011;120:22-7.

32. Asbridge M, Hayden JA, Cartwright JL. Acute cannabis consumption and motor vehicle collision 
risk: systematic review of observational studies and meta-analysis. BMJ 2012;344:e536.

33. Moore TH, Zammit S, Lingford-Hughes A, Barnes TR, Jones PB, Burke M, Lewis G: Cannabis use and risk of psychotic or affective mental health outcomes: a systematic review. Lancet 2007;370:319-28.

34. D'Sousa DC. Cannabinoids and psychosis. Int Rev Neurobiol 2007;78:849-63.

35. Arseneault L, Cannon M, Witton J, Murray RM. Causal association between cannabis and psychosis: examination of the evidence. $\mathrm{Br} \mathrm{J}$ Psychiatry 2004;184:110-7.

36. Di Forti M, Morgan C, Dazzan P, Pariante C, Mondelli V, Marques TR, Handley R, Luzi S, Russo M, Paparelli A, Butt A, Stilo SA, Wiffen B, Powell J, Murray RM. High-potency cannabis and the risk of psychosis. Br J Psychiatry 2009; 195:488-91.

37. Paparelli A, Di Forti M, Morrison PD, Murray RM. Drug-induced psychosis: how to avoid star gazing in schizophrenia research by looking at more obvious sources of light. Front Behav Neurosci 2011;5:1.

38. Newell GR, Mansell PW, Wilson MB, Lynch HK, Spitz MR, Hersh EM. Risk factor analysis among men referred for possible acquired immune deficiency syndrome. Prev Med 1985;14:81-91.

39. Denning DW, Follansbee SE, Scolaro M, et al. Pulmonary aspergillosis in the acquired immunodeficiency syndrome. $\mathrm{N}$ Engl $\mathrm{J}$ Med 1991;324:654-62.
40. Caiaffa WT, Vlahov D, Graham N, Astemborski J, Solomon L, Nelson KE, Muñoz A. Drug smoking, Pneumocystis carinii pneumonia, and immunosuppression increase risk of bacterial pneumonia in human immunodeficiency virusseropositive injection drug users. Am J Respir Crit Care Med 1994;150:1493-8.

41. McCrimmon KK, Mitchell N. Colorado schools see potent influence from nearby medical marijuana sites. Education Week, Feb 6, 2012. Available at www.edweek.org/ew/articles/2012/20/06/21enc_ma rijuana.h31.html. Accessed 6 November 2012.

42. Colorado Department of Public Health and Environment. Colorado Medical Marijuana Registry home page. Available at http://www.colorado.gov/cs/ Satellite/CDPHECHEIS/CBON/1251593016680. Accessed 6 November 2012.

43. Nussbaum AM, Boyer JA, Kondrad EC. "But my doctor recommended pot": medical marijuana and the patient-physician relationship. J Gen Intern Med 2011;26:1364-7.

44. Kondrad E, Reid A. Colorado Family Physicians' Attitudes toward Medical Marijuana. J Am Board Fam Med 2013;26:52-60.

45. Kleber HD, DuPont RL. Physicians and medical marijuana. Am J Psychiatry 2012;169:564-8.

doi:10.5455/2319-2003.ijbcp20130305

Cite this article as: Desai U, Patel P. Medical marijuana: a public health perspective. Int J Basic Clin Pharmacol 2013;2:136-43. 